Article

\title{
Creep Properties Assessment by Shear Punch Creep Test and IMC Morphology of Aged Pb-Free Solder Joint/UBM
}

\author{
Sophal Hai and Hyo-Sun Yu* \\ Division of Mechanical System Engineering, Chonbuk National University, Automotive Technology Research \\ Center, 567 Baekje-daero, Deokjin-gu, Jeonju-si, Jeollabuk-do 54896, Korea; khaisophal@naver.com \\ * Correspondence: hyosun4029@naver.com; Tel.: +82-63-270-2346
}

Received: 8 January 2019; Accepted: 29 January 2019; Published: 11 February 2019

\begin{abstract}
In this paper, we investigated the intermetallic compound (IMC) morphology of aged $(0,200,600 \mathrm{~h})$ conventional $\mathrm{Sn}-37 \mathrm{~Pb}$ and $\mathrm{Pb}$-free $\mathrm{Sn}-4 \mathrm{Ag}-0.5 \mathrm{Cu}$ solder joints/(Ni-P/Au) UBM; the creep properties of the solder joints were evaluated using a shear punch creep test (SPCT) method. The creep displacement-time curves of the solder joints exhibited different behaviors depending on stress application and aging treatment conditions. Empirical formulas such as the Power-law and Monkman-Grant relationship have been used to analyze the SPCT data. Furthermore, the IMC behavior of solder joints was investigated using energy-dispersive X-ray spectroscopy (EDS) and a scanning electron microscope (SEM). The result showed that with an increase of the aging time, the stress exponents $(n)$ of solder joints were decreased, but the IMC thickness and size were increased. In most of the experimental conditions, the creep properties of $\mathrm{Pb}$-free solder joints were superior to the conventional $\mathrm{Sn}-37 \mathrm{~Pb}$ solder joints.
\end{abstract}

Keywords: Pb-free solder joint; aging treatment; IMC; UBM; shear punch creep test (SPCT); creep

\section{Introduction}

Conventional $\mathrm{Sn}-\mathrm{Pb}$ solder joints are commonly used as the most outstanding solder joint for the electronic packaging industry. Over the past decades, they have been used as the most effective bonding material of electronic devices due to their excellent mechanical properties such as a low melting point, wettability and fatigue resistance, and low cost [1,2]. However, conventional Sn-Pb solder alloys are treated as general waste and therefore have bad effects on the environment, such as air and water pollution; they especially have a bad effect on human health [3].

As a result, the European Union (EU) has enacted environmental regulations, which include the restriction of hazardous substances (RoHS), as well as the waste electrical and electronic equipment (WEEE) legislation, to forbid the use of lead $(\mathrm{Pb})$ in electrical and electronic products. For that reason, research on $\mathrm{Pb}$-free solder has received much widespread attention [4,5]; in particular, $\mathrm{Sn}$-Ag-Cu solder alloys are currently known as being the most promising $\mathrm{Pb}$-free solder joints [6]. Sun et al. [7] suggested that in the reflow processing, the eutectic $\mathrm{Sn}-\mathrm{Pb}$ solder joints can be replaced with a eutectic $\mathrm{Sn}-\mathrm{Ag}$-Cu solder joint. In addition, for the wave soldering process, the eutectic $\mathrm{Sn}-\mathrm{Pb}$ solder joint can possibly be replaced with the eutectic $\mathrm{Sn}-\mathrm{Cu}$ alloy as well. In the electronic packaging, Ni-P/Au multilayers have been considered as a promising UBM with a micro-solder bump for flip chip technology due to their functions. This is because they have provided a good solderable surface and also have a function for protecting the underlying copper $(\mathrm{Cu})$ from reacting with the solder, at a low-cost [8]. The IMC behavior is considered a crucial factor for predicting the mechanical properties of solder joints. After $200{ }^{\circ} \mathrm{C}$ HTS aging, the phase microstructure, thickness, and fracture morphology of IMC on the 
interface of SAC solders/UBM have an influence on the pull strength of the joint [9]. On the other hand, the shear punch creep test method has been investigated by many researchers for over twenty years, and it has been applied to evaluate the ductile and brittle materials. As a result, this method is considered as an acceptable tool for determining material creep properties [10]. However, there have been few reports about applying this creep test method using the SPCT for solder joints.

The main purpose of this study is to assess and investigate the creep mechanical properties of aged $\mathrm{Pb}$-free $\mathrm{Sn}-4 \mathrm{Ag}-0.5 \mathrm{Cu}$ solder joints / (Ni-P/Au) UBM using the SPCT method at $30^{\circ} \mathrm{C}$. The isothermal aging was conducted at $150{ }^{\circ} \mathrm{C}$ during $0,200,600 \mathrm{~h}$. Furthermore, the IMC behavior of solder joints was observed using SEM and EDS. The mechanical properties of $\mathrm{Pb}$-free $\mathrm{Sn}-4 \mathrm{Ag}-0.5 \mathrm{Cu}$ solder joints were compared with the conventional $\mathrm{Sn}-37 \mathrm{~Pb}$ solder.

\section{Experimental Section and Preparation of Test Specimens}

\subsection{Materials and Preparation of Test Specimens}

In this research, the conventional $\mathrm{Sn}-37 \mathrm{~Pb}$ solder joints and $\mathrm{Pb}$-free $\mathrm{Sn}-4 \mathrm{Ag}-0.5 \mathrm{Cu}$ solder joints were used to evaluate the creep properties of the solder joint. Figure 1 shows the fabrication process of the specimen for the SPCT method. (Step. 1) The $\mathrm{Cu}$ substrates were machined and polished by sandpaper from \# 800 to \# 2000 grit, to obtain a $10 \times 10 \times 0.8 \mathrm{~mm}$ size and a center hole of $\varnothing 3.2 \mathrm{~mm}$. (Step. 2) Multi-layers of Ni-P/Au UBM, about 5 and $0.1 \mu \mathrm{m}$, respectively, were deposited on the $\mathrm{Cu}$ substrates. (Step. 3) The solder balls were reflowed into the $\mathrm{Cu}$ substrate at reflow temperature (Sn-37Pb: $200{ }^{\circ} \mathrm{C}, \mathrm{Sn}-4 \mathrm{Ag}-0.5 \mathrm{Cu}: 240{ }^{\circ} \mathrm{C}$ ) for $30 \mathrm{~s}$ and were cooled at room temperature for $10 \mathrm{~min}$. (Step. 4) The surfaces of specimens were polished to obtain a final size $(10 \times 10 \times 0.5 \mathrm{~mm})$. (Step. 5) Finally, SP specimens were treated to isothermal aging (AJ-SB4/9908) at $150{ }^{\circ} \mathrm{C}$ for 0,200 , and $600 \mathrm{~h}$. The chemical composition of the solder joints is shown in Table 1. The experiment conditions and melting point temperature of the solder joints is summarized in Table 2.

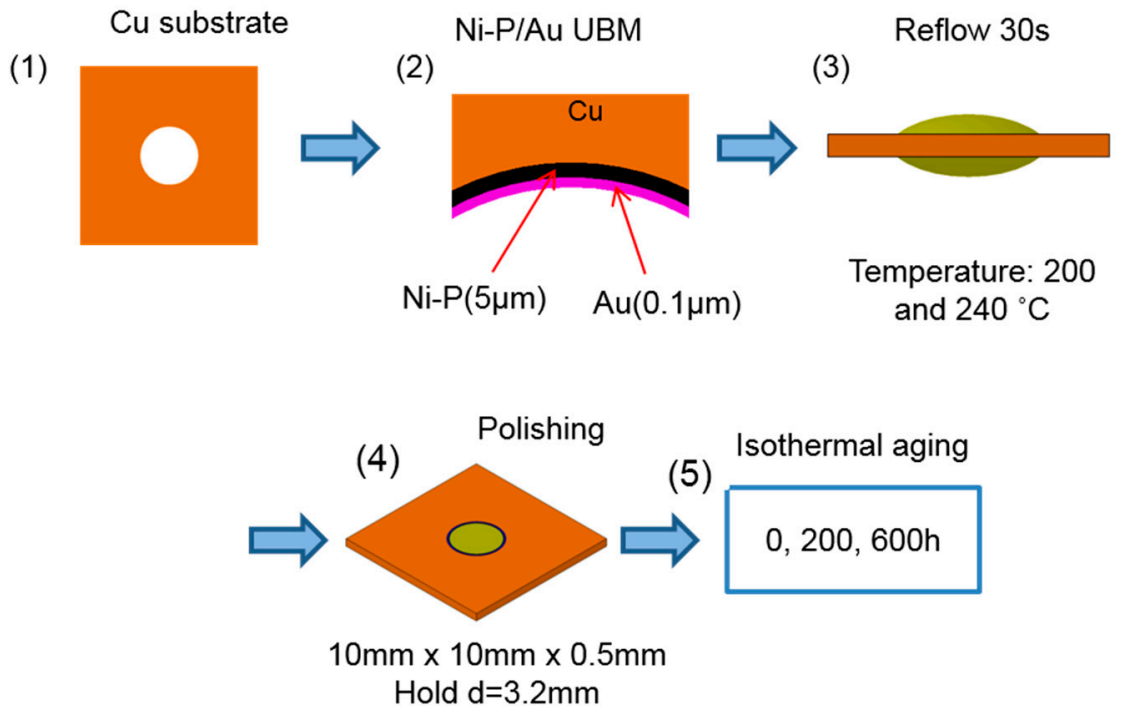

Figure 1. Schematic view for SPCT specimen machining.

Table 1. The chemical composition of solder joints.

\begin{tabular}{|c|c|c|c|c|c|c|c|c|c|c|c|c|}
\hline \multirow{2}{*}{ Solder Joint } & \multicolumn{12}{|c|}{ Chemical Composition (wt. \%) } \\
\hline & Sn & $\mathrm{Pb}$ & $\mathrm{Sb}$ & $\mathrm{Cu}$ & $\mathbf{B i}$ & Zn & $\mathrm{Fe}$ & Al & As & Cd & $\mathrm{Ag}$ & $\mathbf{N i}$ \\
\hline $\mathrm{Sn}-37 \mathrm{~Pb}$ & $62-64$ & Bal- & 0.10 & 0.03 & 0.03 & 0.002 & 0.02 & 0.002 & 0.03 & 0.002 & 0.002 & 0.01 \\
\hline Sn- $4 \mathrm{Ag}-0.5 \mathrm{Cu}$ & Bal- & 0.05 & 0.10 & 0.50 & 0.03 & 0.002 & 0.02 & 0.002 & 0.03 & 0.002 & 4.00 & 0.01 \\
\hline
\end{tabular}


Table 2. The experimental condition and material melting point temperature.

\begin{tabular}{cccccc}
\hline \multicolumn{2}{c}{ Material } & \multicolumn{4}{c}{ SPCT Method } \\
\hline Solder Joint & $\begin{array}{c}\text { Melting Point Temp } \\
\left({ }^{\circ} \mathbf{C}\right)\end{array}$ & $\begin{array}{c}\text { Reflow Temp } \\
\left({ }^{\circ} \mathbf{C}\right)\end{array}$ & $\begin{array}{c}\text { Reflow Time } \\
\text { (s) }\end{array}$ & $\begin{array}{c}\text { SPCT Temp } \\
\left({ }^{\circ} \mathbf{C}\right)\end{array}$ & $\begin{array}{c}\text { Aging Time (h) } \\
\text { and Temp }\left({ }^{\circ} \mathbf{C}\right)\end{array}$ \\
\hline Sn-37Pb & 183 & $200( \pm 5)$ & 30 & 30 & $0,200,600(\mathrm{At}$ \\
$\mathrm{Sn}-4 \mathrm{Ag}-0.5 \mathrm{Cu}$ & 223 & $240( \pm 5)$ & $\left.1500^{\circ} \mathrm{C}\right)$ \\
\hline
\end{tabular}

\subsection{Experimental Method and Conditions}

Figure 2 shows the schematic diagram of the experimental setup for the SPCT method and the deformation of the solder joint during applied stress. Figure 3a shows the photo of the experimental setup for the SPCT equipment, and Figure $3 \mathrm{~b}$ shows the enlarged view of the photo of the specimen setup device. Figure 2a shows a schematic diagram of the whole SPCT composed system. The crucial devices of SPCT are composed of the lower and upper die, furnace, control panel, linear variable differential transformer (LVDT), loading system and computer. Figure $2 \mathrm{~b}$ shows the lower and upper die used to clamp the specimen and to apply a load on the punch. The creep displacement-time curve behavior of both solder joints exhibits the same typical stages as those found in previous research on conventional creep tests, such as primary, secondary and tertiary stages [10]. According to Figure $2 b$, many stresses (i.e., compressive, tensile, and shear stress) were found in Region A. However, the fractures were mostly generated by shear stress followed by both compressive and tensile stresses on the solder joints.

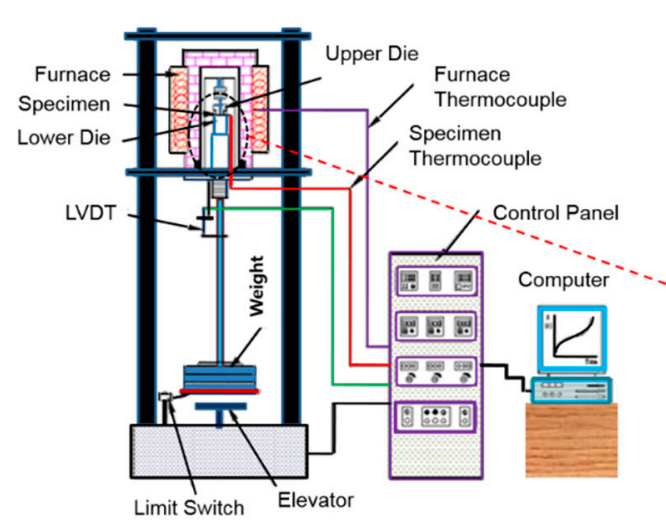

(a) SPCT equipment

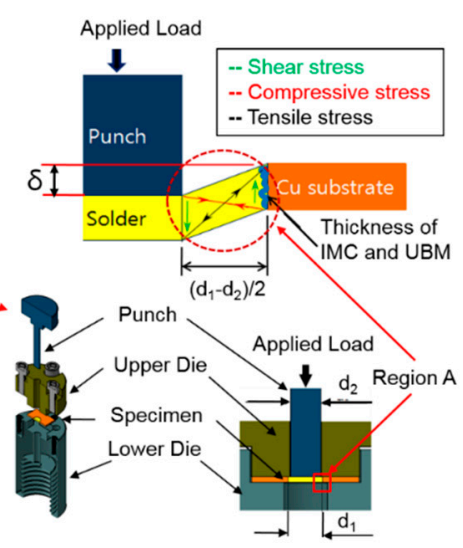

(b) die assembly

Figure 2. Schematic diagram of the experimental setup for the shear punch creep test and the deformation of the solder joint during applied stress.

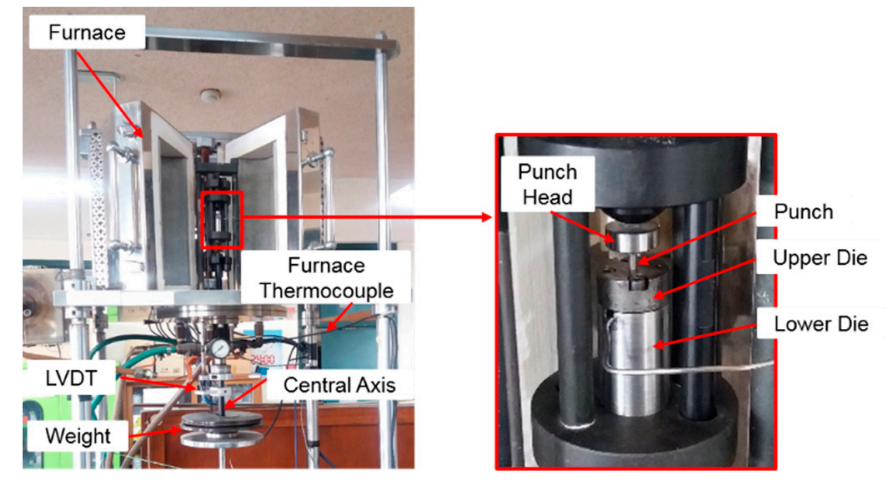

(a) Photo of SPCT equipment

(b) Enlarge view of specimen setup device

Figure 3. Photo of the experimental setup for the shear punch creep test. 
Hence, the main stress applied to the specimens is the average shear stress $(\tau)$, as shown in the following equation [11]:

$$
\tau=\frac{P}{\pi d t}
$$

where $P=$ punch load, $t=$ thickness of the specimen, $d=$ average of $d_{1}$ and $d_{2}\left(d_{2}\right.$ is the diameter of the punch $(\varnothing 2.8 \mathrm{~mm})$, and $d_{1}$ is the diameter of the Cu substrate hold $\left.(\varnothing 3.2 \mathrm{~mm})\right)$. The shear strain $(\varepsilon)$ shown in Figure 2a (Region A) was obtained using the following equation [12]. Here, $\delta$ is the creep displacement that occurs during creep deformation.

$$
\varepsilon=\frac{\delta}{\left(d_{1}-d_{2}\right) / 2}
$$

Figure 4 shows the preparation of a schematic view of the cross-section specimen on Region B. Meanwhile, to analyze the IMC behavior, the cross-section of the specimen was mounted to a thermosetting resin and polished with sandpaper and 0.05 micro aluminum powders. Finally, the interface of the mounted solder joint specimens was etched for $15 \mathrm{~s}$ using a solution $(93 \mathrm{~mL}$ of methanol, $2 \mathrm{~mL}$ of $\mathrm{HCl}$ and $5 \mathrm{~mL}$ of $\mathrm{NHO}_{3}$ ). After that, The IMC behavior at the interface of the cross-section specimens (Region B) was investigated using SEM and EDS.

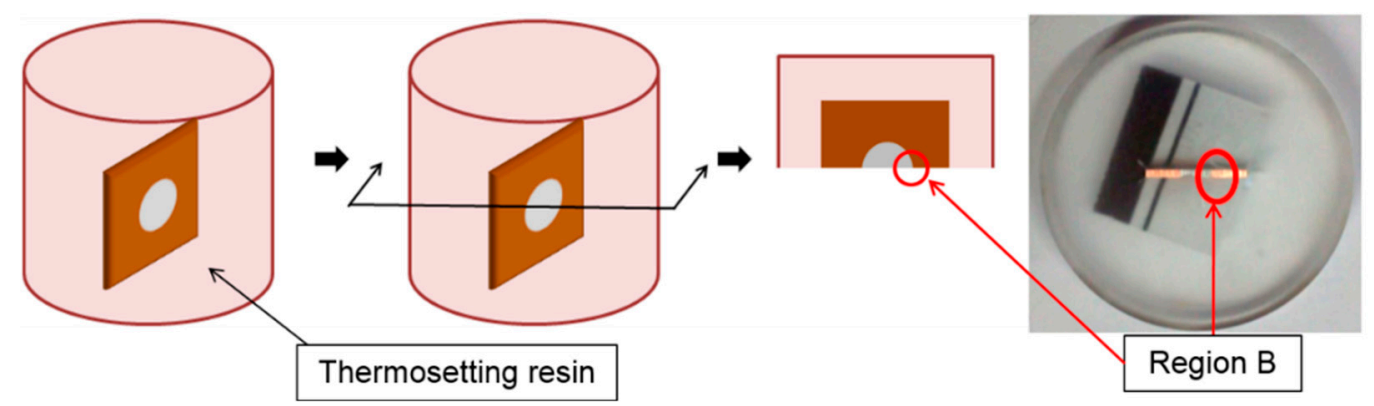

Figure 4. Schematic view of the cross-section specimen on region B.

\section{Result and Discussion}

\subsection{SPCT Displacement-Time Curve}

The creep data obtained from the SPCT method for different aging times is shown in Figures 5 and 6. The creep displacement-time curves of the $\mathrm{Sn}-37 \mathrm{~Pb}$ and $\mathrm{Sn}-4 \mathrm{Ag}-0.5 \mathrm{Cu}$ solder joints are shown in Figures 5 and 6, respectively. The creep curve behavior exhibits the primary, secondary and tertiary stages. It can be seen that the overall creep curves are significantly different from each other according to the aging time and applied load. One can also see that the rupture time significantly decreases with the increase of aging time and applied load. This can be explained due to the brittleness of solder joints and the matrix grain coarsening of IMC that occurred on the interface between the solder joint and $\mathrm{Cu}$ substrates after isothermal aging, thus decreasing the bonding strength between the solder joint and $\mathrm{Cu}$ substrates. In the case of applied loads $49 \mathrm{~N}$ and $53.9 \mathrm{~N}$, the displacements $(\delta)$ of the curves are higher than for other conditions (see Figure $5 b, c$ ). Because the solder joints have a higher elongation property than for other aging time conditions $(200 \mathrm{~h}$ and $600 \mathrm{~h})$, the ductile fractures were predicted to occur in this case. 

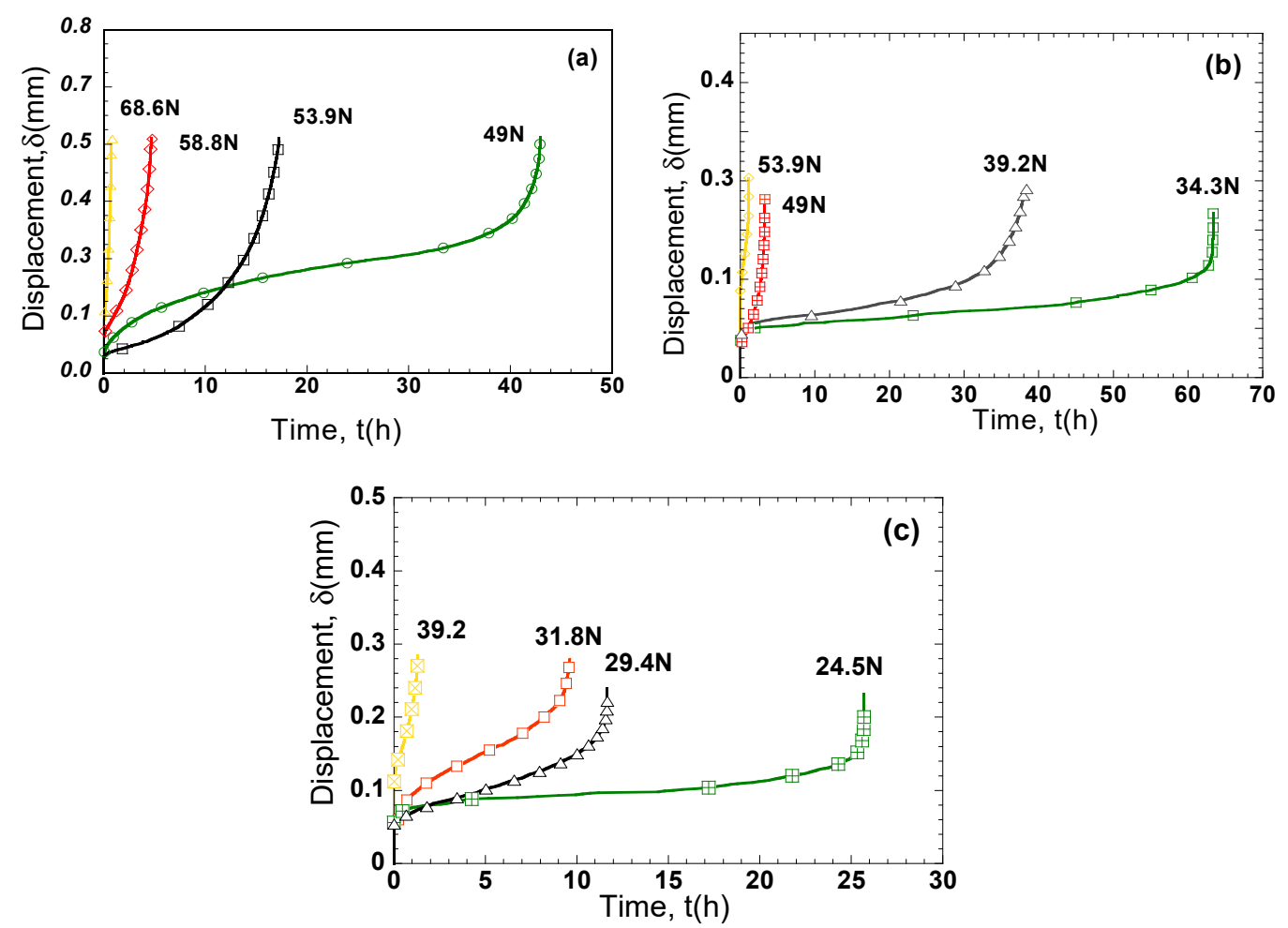

Figure 5. Displacement-time curves for $\mathrm{Sn}-37 \mathrm{~Pb}$ for different aging times (a) $0 \mathrm{~h}$, (b) $200 \mathrm{~h}$, and (c) $600 \mathrm{~h}$.
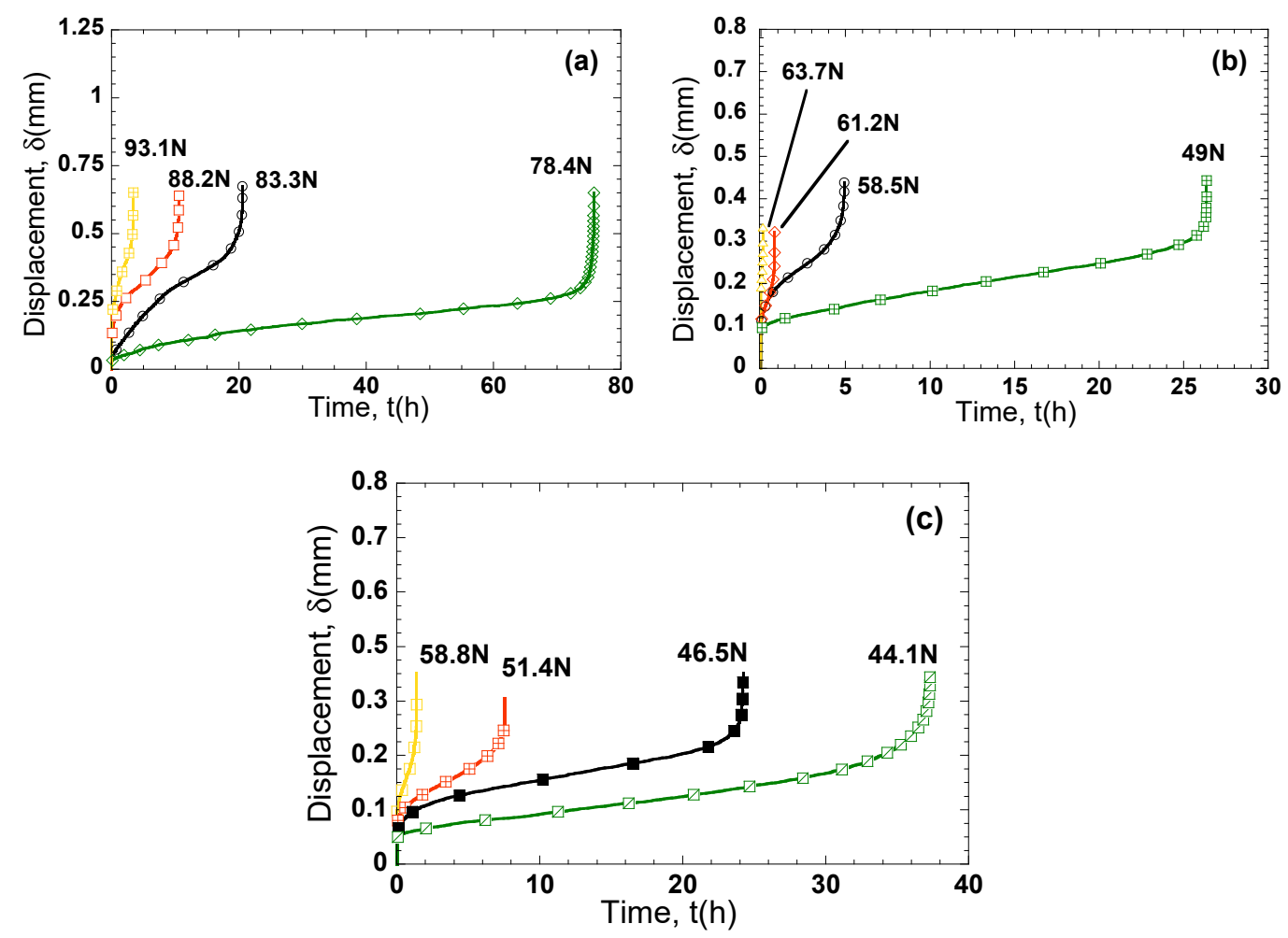

Figure 6. Displacement-time curves for Sn-4Ag-0.5Cu for different aging time (a) $0 \mathrm{~h}$, (b) $200 \mathrm{~h}$, and (c) $600 \mathrm{~h}$.

\subsection{Power-Law Relationship}

Figure 7 shows the power-law relationship between the rupture time of the solder joint $\left(t_{\mathrm{r}}\right)$ and the average shear stress $(\tau)$ for the SPCT method. Figure 6 shows that the creep rupture time of the 
solder joint decreased with an increase of the punch pressure. Equation (3) is a general power law relationship [13]:

$$
t_{\mathrm{r}}=A \tau^{-n}
$$

where, $A=$ material constant, $\tau=$ average shear stress, $n=$ stress exponent. Generally, the stress exponent $(n)$ decreased with an increase of the aging time (see Figure 7). This can be explained by the behavior of the IMC, which changed with an increase in the aging time. This causes the strength of the solder joint to get weaker. The mean thickness of the interfacial $\mathrm{Cu}_{5} \mathrm{Zn}_{8} \mathrm{IMC}$ layers in the specimen increased with an increase in the thermal aging time, following a parabolic law [14]. The stress exponent $(n)$ of the $\mathrm{Pb}$-free solder joints is higher than $\mathrm{Sn}-37 \mathrm{~Pb}$ at the same temperature. Commonly, the creep life of $\mathrm{Pb}$-free $\mathrm{Sn}-4 \mathrm{Ag}-0.5 \mathrm{Cu}$ solder joints are longer than that of $\mathrm{Sn}-37 \mathrm{~Pb}$ solder joints.

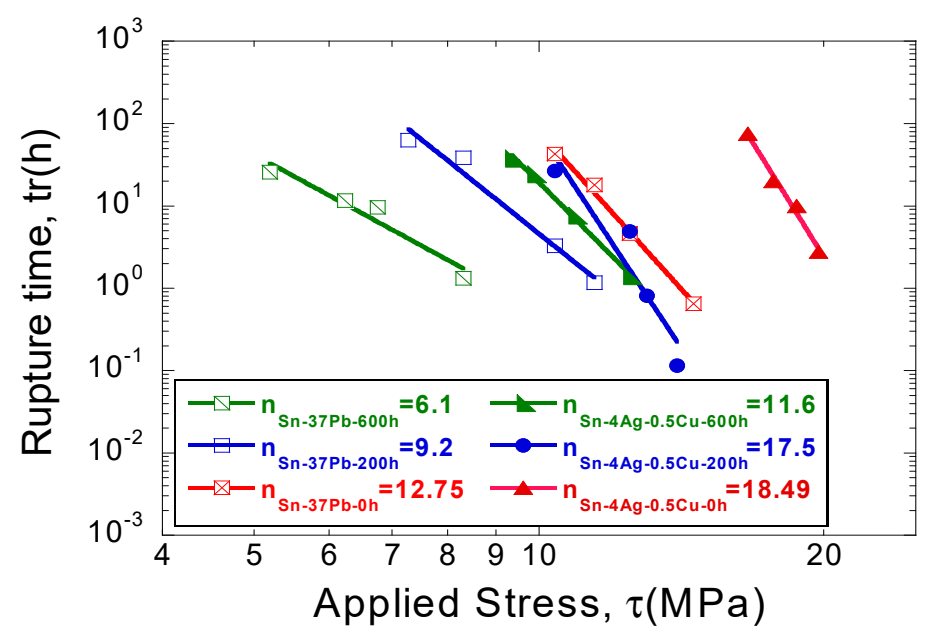

Figure 7. Power law relationships for both aged solders joints.

The creep rupture time $\left(t_{\mathrm{r}}\right)$ of the solder joints with the aging time was calculated using the following power law relationship equation:

The power law relationship equation of $\mathrm{Sn}-37 \mathrm{~Pb}$ and $\mathrm{Sn}-4 \mathrm{Ag}-0.5 \mathrm{Cu}$ solder joints:

$$
\begin{array}{ccc}
\text { - } & \text { Sn-37Pb solder joint } & \text { Sn-4Ag-0.5Cu solder joint } \\
\text {-Aging 0 } \mathrm{h} & t_{\mathrm{r}}=4.48 \times 10^{14} \cdot \tau^{-12.75} & t_{\mathrm{r}}=2.75 \times 10^{24} \cdot \tau^{-18.49} \\
\text {-Aging 200 } \mathrm{h} & t_{\mathrm{r}}=7.4 \times 10^{9} \cdot \tau^{-9.2} & t_{\mathrm{r}}=1.78 \times 10^{20} \cdot \tau^{-17.5} \\
\text {-Aging 600 } \mathrm{h} & t_{\mathrm{r}}=9.94 \times 10^{5} \cdot \tau^{-6.1} & t_{\mathrm{r}}=7.49 \times 10^{12} \cdot \tau^{-11.6}
\end{array}
$$

\subsection{Monkman-Grant Relationship}

The Monkman-Grant relational equation is widely used in the creep failure modeling. It has also been used to evaluate this experiment to predict the creep rupture time [15]. This relationship is obtained from the relationship between the creep strain rate $(\dot{\varepsilon})$ and the creep rupture time $\left(t_{\mathrm{r}}\right)$, as follows.

$$
t_{\mathrm{r}} \dot{\varepsilon}^{m}=b
$$

where, $t_{\mathrm{r}}=$ fracture time, $m=$ Monkman-Grant exponent, $b=$ material constant. The slope of the relationship plot is approximately 1 and indicates that it is valid for the SPCT method [16]. Figure 8 shows that the Monkman-Grant relationship of both solder joints in relation to the creep strain rate $(\dot{\varepsilon})$ and the creep rupture time $\left(t_{\mathrm{r}}\right)$ for different aging times. The Monkman-Grant exponents $(m)$ of the solder joints are 0.71 and 1.1, which is close to 1 . This means that the SPCT method applies in the 
assessment of the creep mechanical properties of both the conventional and the $\mathrm{Pb}$-free solder joints. The Monkman-Grant relationship of each solder joint is as follows:

$$
\begin{gathered}
\text { Sn-37Pb: } t_{\mathrm{r}} \dot{\varepsilon}^{0.71}=0.18 \\
\text { Sn-4Ag-0.5Cu: }: t_{\mathrm{r}} \dot{\varepsilon}^{1.1}=0.03
\end{gathered}
$$
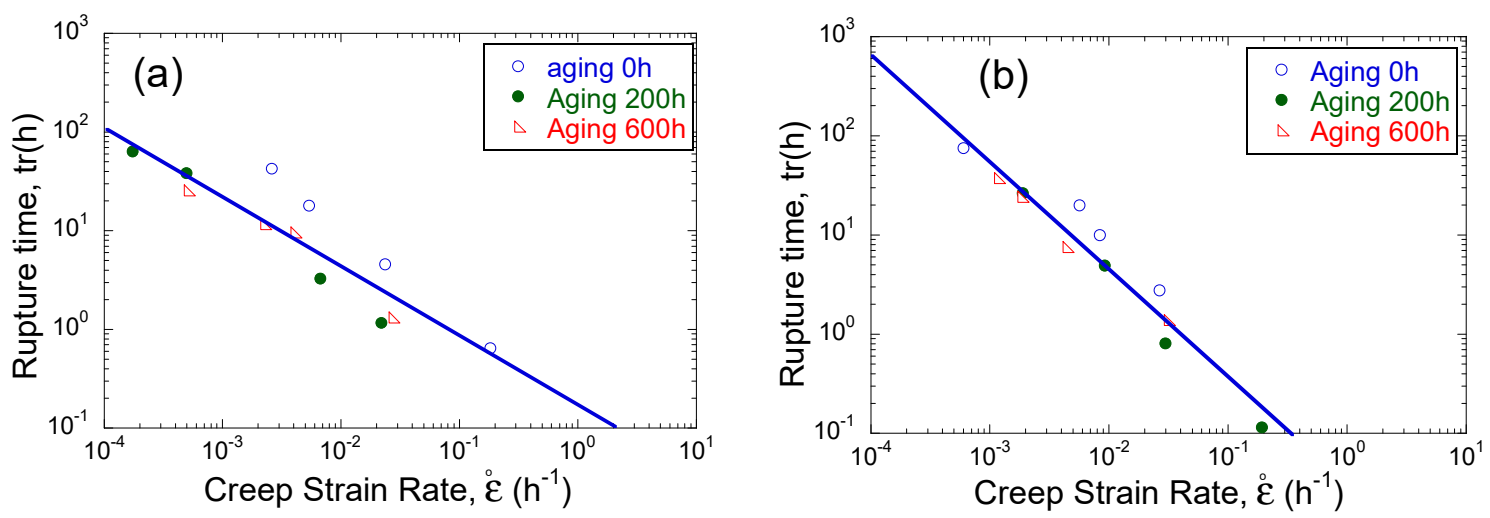

Figure 8. Monkman-Grant relationship of (a) $\mathrm{Sn}-37 \mathrm{~Pb}$ and (b) $\mathrm{Sn}-4 \mathrm{Ag}-0.5 \mathrm{Cu}$.

\subsection{Observation of IMC Behavior}

We also investigated the IMC formation during the high-temperature reflow process in order to assess and evaluate the properties of the solder joints. However, the overgrowth of IMC leads to brittleness, which causes brittle fracture and the deterioration of the bonding strength between the solder joint and substrate. As a result, the observation of the IMC formation is an essential factor for solder joints [9,17]. Figures 9 and 10 show the phase and morphology of IMC of each solder joint using SEM and EDS after aging at $150{ }^{\circ} \mathrm{C}$ for 0,200 , and $600 \mathrm{~h}$ respectively. The results obtained from Figures 9 and 10 show that for both solders the thickness of the IMC layer at the $\mathrm{Cu}$ interface gradually increases with the aging time. The IMC morphology changed significantly from a stable to irregular state and from a small round to long needle-like shape when the aging time increased. Figure 9 shows the IMC $\mathrm{Ni}_{3} \mathrm{Sn}_{4}, \mathrm{Sn}$-rich, and Pb-rich phases for 0 and $200 \mathrm{~h}$ aging. In addition, voids and other IMC phases $(\mathrm{Cu}, \mathrm{Ni})_{6} \mathrm{Sn}_{5}$ were observed at $600 \mathrm{~h}$. This changed behavior of the IMC at the $\mathrm{Cu}$ interface shows that the initial ductility is gradually evolving to brittleness with increasing aging time. Figure 10 shows that the IMC phase $\left(\mathrm{Cu}, \mathrm{Ni}_{6} \mathrm{Sn}_{5}, \mathrm{Ni}_{3} \mathrm{Sn}_{4}\right.$ was observed from an aging time of $200 \mathrm{~h}$, and that the voids appeared for an aging time of $600 \mathrm{~h}$. Overall, the IMC interface of the Sn-4Ag-0.5Cu solder joints was found to be more stable than that of the $\mathrm{Sn}-37 \mathrm{~Pb}$ solder. 

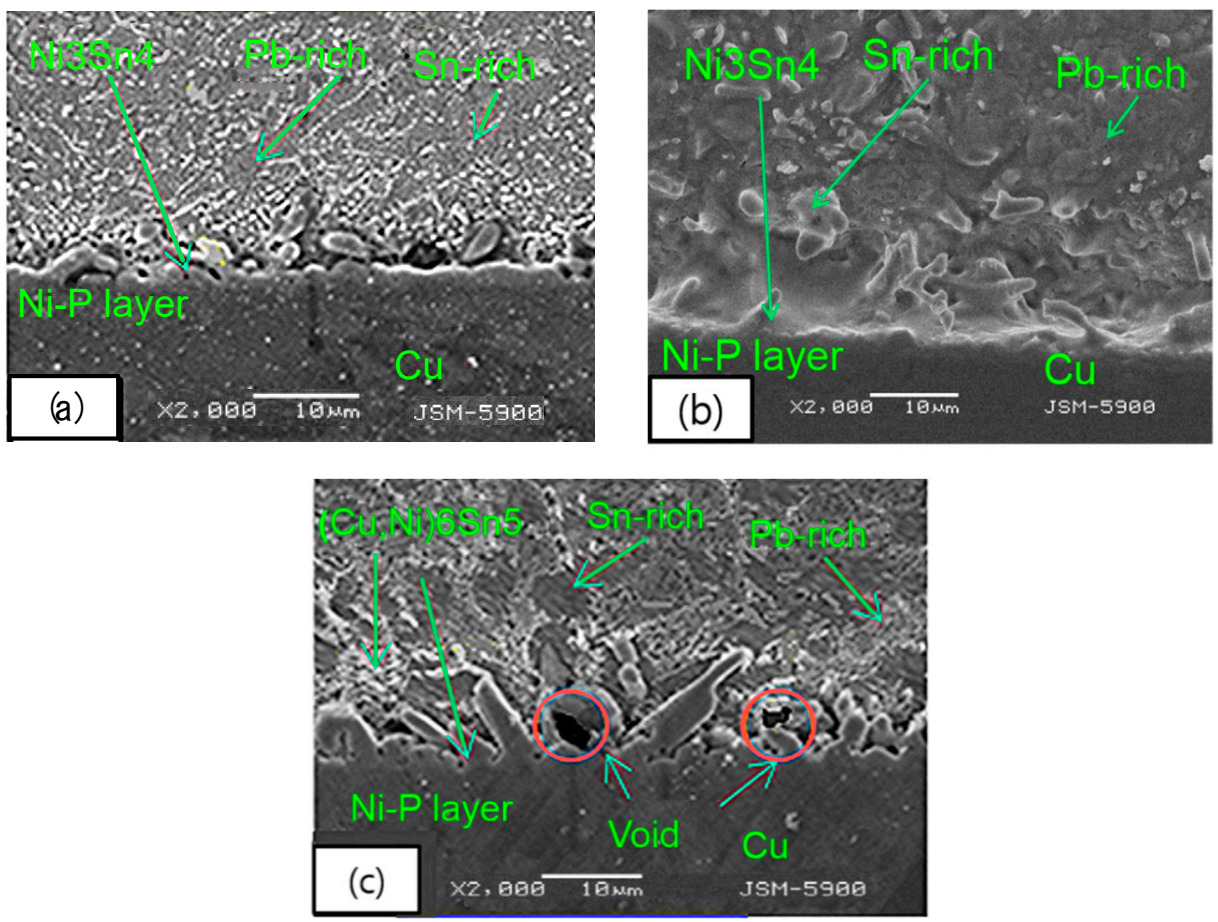

Figure 9. SEM images of Sn-37Pb after aging time (a) $0 \mathrm{~h}$, (b) $200 \mathrm{~h}$, and (c) $600 \mathrm{~h}$.
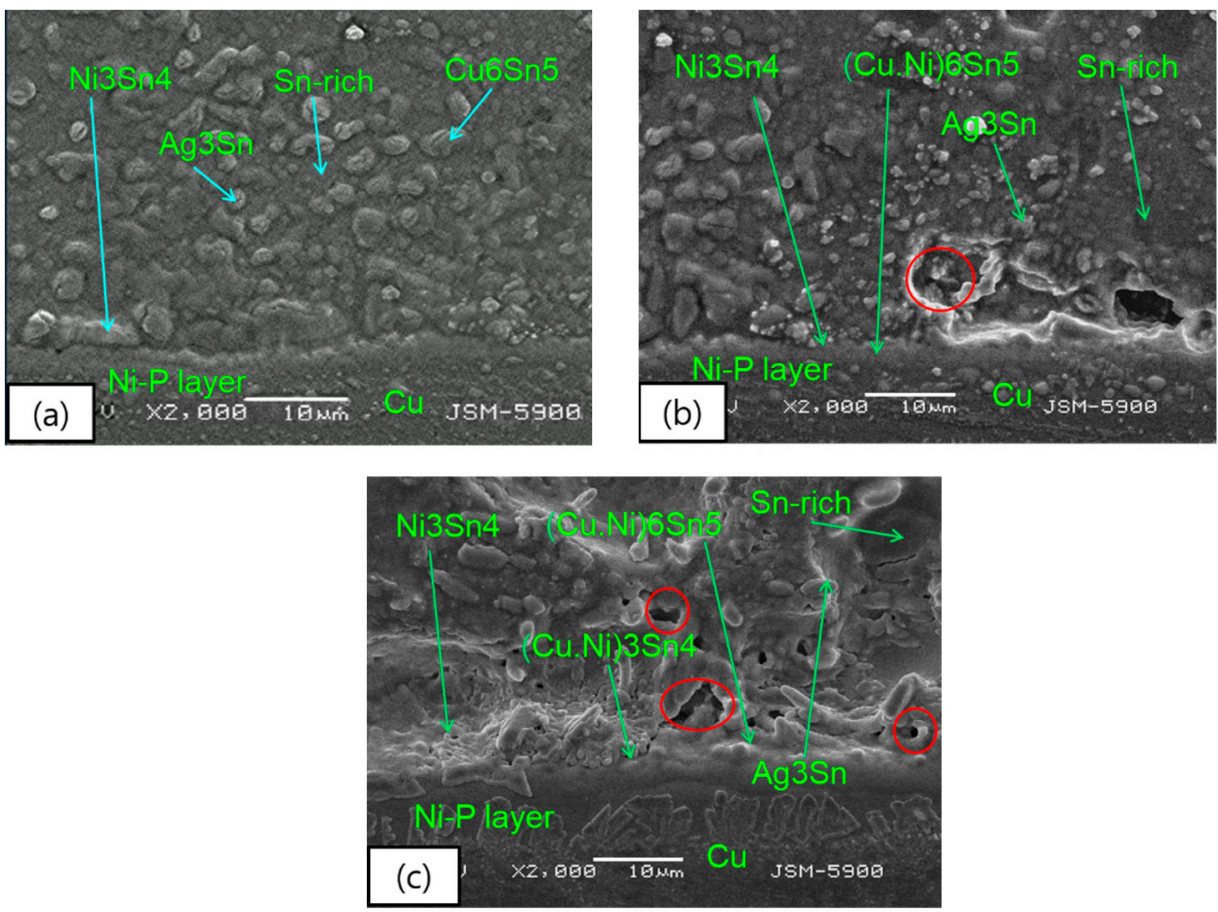

Figure 10. SEM images of Sn-4Ag-0.5Cu after aging time (a) 0 h, (b) $200 \mathrm{~h},(\mathbf{c})$ and $600 \mathrm{~h}$.

\section{Conclusions}

In this research, we evaluated the creep mechanical properties of $\mathrm{Sn}-37 \mathrm{~Pb}$ and $\mathrm{Sn}-4 \mathrm{Ag}-0.5 \mathrm{Cu}$ solder joints for different aging times $(0,200,600 \mathrm{~h})$ by investigating IMC behavior and using the SPCT method. The conclusions of this study are summarized as follows.

1. Based on the results of the SEM micro images, the thickness of the IMC increased, and the shape of the IMC morphologies changed from round to needle-like with an increase of the aging time. After isothermal aging $(200$ and $600 \mathrm{~h})$, the $\mathrm{IMC}\left(\mathrm{Cu}, \mathrm{Ni}_{6} \mathrm{Sn}_{5}\right.$ phases and the micro voids were 
found on the solder joint/Cu substrate interface. This means that the brittleness of the solder increased, thus causing the deterioration of mechanical properties.

2. The power-law relationship indicated that the stress exponent $(n)$ and creep properties of solder joints decreased with the increase of aging time, and that the values $(n)$ of $\mathrm{Sn}-4 \mathrm{Ag}-0.5 \mathrm{Cu}$ solder joints are higher than those of $\mathrm{Sn}-37 \mathrm{~Pb}$ solder joints. It can thus be confirmed that the creep properties of $\mathrm{Sn}-4 \mathrm{Ag}-0.5 \mathrm{Cu}$ solder joints are better than those of conventional $\mathrm{Sn}-37 \mathrm{~Pb}$ solder joints.

3. The Monkman-Grant relationship shows that the exponent value $(m)$ solder joints are close to 1. It can thus be confirmed that the SPCT method is a reliable method, which can be used to evaluate the creep properties of solder joints.

4. Based on our results, the obtained mechanical properties of $\mathrm{Pb}$-free $\mathrm{Sn}-4 \mathrm{Ag}-0.5 \mathrm{Cu}$ solder joints are greater than those of $\mathrm{Sn}-37 \mathrm{~Pb}$ solder joints for all isothermal aging time conditions $(0,200$, $600 \mathrm{~h}$ ). In addition, the melting point temperature of $\mathrm{Sn}-4 \mathrm{Ag}-0.5 \mathrm{Cu}$ solder joints is similar to that of conventional $\mathrm{Sn}-37 \mathrm{~Pb}$ solder joints. Therefore, it is possible to use $\mathrm{Pb}$-free $\mathrm{Sn}-4 \mathrm{Ag}$ - $0.5 \mathrm{Cu}$ solder joints in electrical applications, rather than $\mathrm{Sn}-37 \mathrm{~Pb}$ solder joints.

Author Contributions: Conceptualization, S.H. and H.S.Y.; methodology, S.H.; software, S.H.; formal analysis, S.H. and H.S.Y.; investigation, H.S.Y.; data curation, S.H.; writing-original draft preparation, S.H.; writing-review and editing, H.S.Y.

Funding: This work was supported by Chonbuk National University, the Republic of Korea in 2018.

Conflicts of Interest: The authors have no conflict of interest to declare.

\section{References}

1. Kotadia, H.R.; Howes, P.D.; Mannan, S.H. A review: On the development of low melting temperature Pb-free solders. Microelectron. Reliab. 2014, 54, 1253-1273. [CrossRef]

2. Liu, C.-Y.; Hon, M.-H.; Wang, M.-C.; Chen, Y.-R.; Chang, K.-M.; Li, W.-L. Effects of aging time on the mechanical properties of Sn-9Zn-1.5Ag-xBi lead-free solder alloys. J. Alloys Compd. 2014, 582, 229-235. [CrossRef]

3. Chang, S.Y.; Jain, C.C.; Chuang, T.H.; Feng, L.P.; Tsao, L.C. Effect of addition of $\mathrm{TiO}_{2}$ nanoparticles on the microstructure, microhardness and interfacial reactions of Sn3.5AgXCu solder. Mater. Des. 2011, 32, 4720-4727. [CrossRef]

4. Tseng, C.-F.; Jill Lee, C.; Duh, J.-G. Roles of $\mathrm{Cu}$ in Pb-free solders jointed with electroless $\mathrm{Ni}(\mathrm{P})$ plating. Mater. Sci. Eng. A 2013, 574, 60-67. [CrossRef]

5. Koo, J.; Lee, C.; Hong, S.J.; Kim, K.-S.; Lee, H.M. Microstructural discovery of Al addition on Sn-0.5Cu-based Pb-free solder design. J. Alloys Compd. 2015, 650, 106-115. [CrossRef]

6. Khodabakhshi, F.; Sayyadi, R.; Javid, N.S. Lead free $\mathrm{Sn}$-Ag-Cu solders reinforced by Ni-coated graphene nanosheets prepared by mechanical alloying: Microstructural evolution and mechanical durability. Mater. Sci. Eng. A 2017, 702, 371-385. [CrossRef]

7. Sun, P.; Andersson, C.; Wei, X.; Cheng, Z.; Shangguan, D.; Liu, J. High temperature aging study of intermetallic compound formation of $\mathrm{Sn}-3.5 \mathrm{Ag}$ and $\mathrm{Sn}-4.0 \mathrm{Ag}-0.5 \mathrm{Cu}$ solders on electroless $\mathrm{Ni}(\mathrm{P})$ metallization. J. Alloys Compd. 2006, 425, 191-199. [CrossRef]

8. Islam, M.N.; Chan, Y.C.; Sharif, A.; Rizvi, M.J. Effect of 9 wt.\% in addition to Sn3.5Ag0.5Cu solder on the interfacial reaction with the $\mathrm{Au} / \mathrm{NiP}$ metallization on $\mathrm{Cu}$ pads. J. Alloys Compd. 2005, 396, 217-223. [CrossRef]

9. Sun, F.; Hochstenbach, P.; Van Driel, W.D.; Zhang, G.Q. Fracture morphology and mechanism of IMC in Low-Ag SAC Solder/UBM (Ni(P)-Au) for WLCSP. Microelectron. Reliab. 2008, 48, 1167-1170. [CrossRef]

10. Hou, F.; Xu, H.; Wang, Y.; Zhang, L. Determination of creep property of 1.25Cr0.5Mo pearlitic steels by small punch test. Eng. Fail. Anal. 2013, 28, 215-221. [CrossRef]

11. Mahmudi, R.; Maraghi, A. Shear punch creep behavior of cast lead-free solders. Mater. Sci. Eng. A 2014, 599, 180-185. [CrossRef] 
12. Guduru, R.K.; Darling, K.A.; Kishore, R.; Scattergood, R.O.; Koch, C.C.; Murty, K.L. Evaluation of mechanical properties using shear-punch testing. Mater. Sci. Eng. A 2005, 395, 307-314. [CrossRef]

13. Dobeš, F.; Milička, K. Application of creep small punch testing in assessment of creep lifetime. Mater. Sci. Eng. A 2009, 510-511, 440-443. [CrossRef]

14. Liu, L.; Zhou, W.; Li, B.; Wu, P. Interfacial reactions between $\mathrm{Sn}-8 \mathrm{Zn}-3 \mathrm{Bi}-x \mathrm{Ni}$ lead-free solders and $\mathrm{Cu}$ substrate during isothermal aging. Mater. Chem. Phys. 2010, 123, 629-633. [CrossRef]

15. Komazaki, S. Evaluation of creep rupture strength of high nitrogen ferritic heat-resistant steels using small punch creep testing technique. Mater. Sci. Eng. A 2016, 676, 100-108. [CrossRef]

16. Nakata, T.; Komazaki, S.; Kohno, Y.; Tanigawa, H. Development of a small punch testing method to evaluate the creep property of high Cr ferritic steel: Part I-Effect of atmosphere on creep deformation behavior. Mater. Sci. Eng. A 2016, 666, 54-60. [CrossRef]

17. Chen, Y.J.; Chung, C.K.; Yang, C.R.; Kao, C.R. Single-joint shear strength of micro Cu pillar solder bumps with different amounts of intermetallics. Microelectron. Reliab. 2013, 53, 47-52. [CrossRef]

(C) 2019 by the authors. Licensee MDPI, Basel, Switzerland. This article is an open access article distributed under the terms and conditions of the Creative Commons Attribution (CC BY) license (http://creativecommons.org/licenses/by/4.0/). 